\title{
Article \\ Distribution of CRISPR in Escherichia coli Isolated from Bulk Tank Milk and Its Potential Relationship with Virulence
}

\author{
Hyo-Jung Kang (1) and Young-Ju Lee * \\ College of Veterinary Medicine and Zoonoses Research Institute, Kyungpook National University, \\ Daegu 41566, Korea; sa01083@knu.ac.kr \\ * Correspondence: youngju@knu.ac.kr; Tel.: +82-53-950-7793
}

check for updates

Citation: Kang, H.-J.; Lee, Y.-J. Distribution of CRISPR in Escherichia coli Isolated from Bulk Tank Milk and Its Potential Relationship with Virulence. Animals 2022, 12, 503. https://doi.org/10.3390/ani 12040503

Academic Editor: Bianca Castiglioni

Received: 30 December 2021

Accepted: 15 February 2022

Published: 17 February 2022

Publisher's Note: MDPI stays neutral with regard to jurisdictional claims in published maps and institutional affiliations.

Copyright: () 2022 by the authors. Licensee MDPI, Basel, Switzerland. This article is an open access article distributed under the terms and conditions of the Creative Commons Attribution (CC BY) license (https:// creativecommons.org/licenses/by/ $4.0 /)$.
Simple Summary: In the dairy farms of many different countries, E. coli is one of the most common causes of mastitis. It is defined as mammary pathogenic E. coli, and is known to cause opportunistic infections by possessing diverse virulence factors. Therefore, the purpose of this study was to investigate the virulence potential of $E$. coli isolates from bulk tank milk in Korea, and observe its association with clustered regularly interspaced short palindromic repeat (CRISPR) arrays. The results showed that out of 183 isolates, $164(89.6 \%)$ possessed one or more of 18 virulence genes, and belonged to phylogenetic groups B1 (64.0\%), A (20.1\%), D (8.5\%), and C (7.3\%). CRISPR arrays of E. coli are classified as either CRISPR I-E (CRISPR 1 and 2) or CRISPR I-F (CRISPR 3 and 4). In this study, only CRISPR 1 (95.7\%) and 2 (74.4\%) were detected. Among the eight protospacers matching plasmids and phages, three were associated with gene regulation, and one was associated with virulence. Moreover, the different virulence genes showed significantly different patterns of CRISPR distribution and CRISPR sequence-types. This result implies that CRISPR loci may be associated with gene regulation and pathogenicity in E. coli, and that the CRISPR sequence-typing approach can help to clarify and trace virulence potential, even though the E. coli isolates were from normal bulk tank milk.

\begin{abstract}
Escherichia coli is one of the most common causes of mastitis on dairy farms around the world, but its clinical severity is determined by a combination of virulence factors. Recently, clustered regularly interspaced short palindromic repeat (CRISPR) arrays have been reported as a novel typing method because of their usefulness in discriminating pathogenic bacterial isolates. Therefore, this study aimed to investigate the virulence potential of $E$. coli isolated from bulk tank milk, not from mastitis, and to analyze its pathogenic characterization using the CRISPR typing method. In total, $164(89.6 \%)$ out of 183 E. coli isolated from the bulk tank milk of 290 farms carried one or more of eighteen virulence genes. The most prevalent virulence gene was fim $\mathrm{H}(80.9 \%)$, followed by iss (38.3\%), $\operatorname{traT}(26.8 \%)$, ompT (25.7\%), afa/draBC (24.0\%), and univcnf (21.9\%). Moreover, the phylogenetic group with the highest prevalence was B1 (64.0\%), followed by A $(20.1 \%), \mathrm{D}(8.5 \%)$, and C $(7.3 \%)(p<0.05)$. Among the four CRISPR loci, only two, CRISPR 1 and CRISPR 2, were found. Interestingly, the distribution of CRISPR 1 was significantly higher in groups A and B1 compared to that of CRISPR 2 $(p<0.05)$, but there were no significant differences in groups $C$ and $D$. The prevalence of CRISPR 1 by virulence gene ranged from $91.8 \%$ to $100 \%$, whereas that of CRISPR 2 ranged from $57.5 \%$ to $93.9 \%$. The distribution of CRISPR 1 was significantly higher in fimH, ompT, afa/draBC, and univcnf genes than that of CRISPR $2(p<0.05)$. The most prevalent E. coli sequence types (EST) among 26 ESTs was EST 22 (45.1\%), followed by EST 4 (23.2\%), EST 16 (20.1\%), EST 25 (19.5\%), and EST 24 (18.3\%). Interestingly, four genes, fimH, ompT, afa/draBC, and univcnf, had a significantly higher prevalence in both EST 4 and EST $22(p<0.05)$. Among the seven protospacers derived from CRISPR 1, protospacer 163 had the highest prevalence (20.4\%), and it only existed in EST 4 and EST 22. This study suggests that the CRISPR sequence-typing approach can help to clarify and trace virulence potential, although the E. coli isolates were from normal bulk tank milk and not from mastitis.
\end{abstract}

Keywords: E. coli; virulence gene; phylogeny; CRISPR array; bulk tank milk 


\section{Introduction}

Escherichia coli is one of the most common Gram-negative bacteria residing in the intestines of animals in an anaerobic and facultative manner [1]; however, it is also one of the most common causes of mastitis on dairy farms [2]. Generally, E. coli mastitis results in a subclinical pathology caused by an environmental opportunistic infection. However, the presence of diverse virulence properties associated with extraintestinal pathogenesis, such as adhesins, toxins, capsule synthesis, siderophores, invasins, and serum survival, is reported to be crucial for the colonization of the mammary glands via increased bacterial survival and tissue damage [3,4]. In particular, Aslam et al. (2021) [5] reported that the presence of various virulence genes in extraintestinal pathogenic E. coli (ExPEC) contributed to the rise in mammary pathogenic E. coli (MPEC).

Moreover, the virulence potential necessary to cause an infection of the mammary glands is determined by a combination of factors, not the presence of a single factor [6]. Hence, phylogenetic analysis is important because it enriches the understanding of the classification, and determines the virulence of pathogenic E. coli $[7,8]$. E. coli is derived from different phylogenetic groups A, B1, B2, C, D, E, and F [9], and the majority of strains responsible for ExPEC, such as uropathogenic E. coli (UPEC), newborn meningitisassociated E. coli, and avian pathogenic E. coli, belong to groups B2 and D $[10,11]$. However, even though MPEC can cause infections outside of the gastrointestinal system, both MPEC and bovine commensals belong to phylogroups A and B1, because MPEC may be recruited from the normal intestinal commensal microbiota [12-14].

Clustered regularly interspaced short palindromic repeat (CRISPR) arrays are a bacterial adaptive immune system that neutralizes invading phages and plasmids by cutting foreign DNA at specific locations. It consists of various spacers, which are short sequences between each repeat [15-17]. A protospacer, which is a short external sequence at a specific location, is inserted as a spacer in the CRISPR loci of bacteria during an infection [18]. Recently, CRISPR arrays have been applied as a novel typing method for isolates because they are useful in discriminating the pathogenicity of Salmonella [19], E. coli [20-25], and Pseudomonas aeruginosa [26]. This study aimed to investigate the virulence potential of E. coli isolated from bulk tank milk, not from mastitis, and to analyze the pathogenic characterization of E. coli using the CRISPR typing method.

\section{Materials and Methods}

\subsection{Bacterial Strains}

Each $50 \mathrm{~mL}$ of bulk tank milk was aseptically collected, from 290 farms operated by three dairy companies, and tested in accordance with the standard microbiological protocols published by the Ministry of Food and Drug Safety (2018) [27]. Approximately $1 \mathrm{~mL}$ of each bulk tank milk sample was inoculated into $9 \mathrm{~mL}$ of modified Escherichia coli broth (Merck, Darmstadt, Germany), and these were incubated at $37^{\circ} \mathrm{C}$ for $24 \mathrm{~h}$. A loopful of enriched mEC was streaked onto MacConkey agar (BD Bioscience), and incubated at $37^{\circ} \mathrm{C}$ for $24 \mathrm{~h}$. Three typical colonies selected from each sample were confirmed by PCR, as described previously [28]. If isolates of the same origin showed the same antimicrobial susceptibility patterns, only one isolate was randomly chosen, and a total of $183 \mathrm{E}$. coli were included in this study.

\subsection{Detection of Virulence Genes}

A total of 33 virulence genes associated with ExPEC (afa/draBC, bmaE, cdt, cdtB,

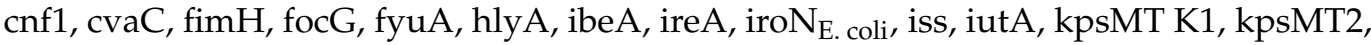
kpsMT3, kpsMT K5, nfaE, ompT, PAI, papAH, papC, papEF, papG allele 1, papG allele 2, papG allele 3, rfc, sfa/focDE, sfaS, traT, and univcnf) were screened by PCR, as described previously [29]. 


\subsection{Phylogenetic Groups}

Phylogenetic grouping was accomplished by a multiplex PCR-based method using chuA, yjaA, TSPE4.C2, arpA, and $\operatorname{trp} A$ genes, and the bacteria were assigned into groups $\mathrm{A}$, B1, B2, C, D, E, F, and clade I, as described previously [9].

\subsection{CRISPR Locus Sequence Typing and Spacer Analysis}

Four CRISPR loci were screened by PCR, as described previously [22]. The PCR products were purified using a QIAquick PCR purification kit (Qiagen, Hilden, Germany), and sequenced using an automatic sequencer (Cosmogenetech, Seoul, Korea). Sequences were analyzed by CRISPRFinder (https: / / crispr.i2bc.paris-saclay.fr/Server/, accessed on 31 August 2021), as described by Grissa et al. (2007) [30], and only spacers were obtained for this study. All E. coli were categorized into E. coli sequence types (ESTs) based on their spacer distributions, numbered arbitrarily. The name and full sequences of all spacers are listed in Supplementary Table S1. CRISPRTarget (http:/ / crispr.otago.ac.nz/CRISPRTarget/ crispr_analysis.html, accessed on 31 August 2021) with a cut-off value of 29, and nucleotide BLAST (https://blast.ncbi.nlm.nih.gov/Blast.cgi, accessed on 10 September 2021) were used to detect protospacers derived from phages or plasmids [31].

\subsection{Statistical Analysis}

Analysis via the Statistical Package for the Social Sciences version 25 (IBM SPSS Statistics for Windows, Armonk, NY, USA) was used in this study. Pearson's chi-square test and Fisher's exact test with Bonferroni correction were conducted to analyze the differences associated with the distribution of virulence genes, phylogenetic groups, and ESTs. A $p$-value $<0.05$ was considered statistically significant.

\section{Results}

\subsection{Distribution of Virulence Genes}

The distribution of 33 virulence genes associated with ExPEC in E. coli from bulk tank milk is presented in Table 1. A total of $164(89.6 \%)$ out of 183 E. coli isolated from bulk tank milk carried one or more of eighteen virulence genes. The most prevalent virulence gene was fimH $(80.9 \%)$, followed by iss $(38.3 \%)$, traT $(26.8 \%)$, ompT $(25.7 \%)$, afa/draBC $(24.0 \%)$, and univcnf $(21.9 \%)$. Interestingly, both iss and traT had the significantly highest prevalence in $E$. coli from company A, and fim $H$ had a significantly higher prevalence in E. coli from companies A and B $(p<0.05)$. Although kpsMTK5 had a low prevalence $(7.1 \%)$ in E. coli, this gene also showed a significant difference among the companies $(p<0.05)$.

\subsection{Distribution of Phylogenetic Groups and CRISPR Loci}

The distribution of phylogenetic groups and CRISPR loci in $164 \mathrm{E}$. coli isolates with some virulence genes is presented in Table 2 . All isolates were assigned into four phylogenetic groups: A, B1, C, and D. The phylogenetic group with the significantly highest prevalence was B1 (64.0\%), followed by A $(20.1 \%)$, D (8.5\%), and C (7.3\%). Although the distribution of groups B1 and $C$ was not significantly different by company, that of groups A and D showed significant differences between companies $(p<0.05)$. Among the four CRISPR loci examined, only two, CRISPR 1 and CRISPR 2, were found. However, the prevalence of CRISPR 1 (95.7\%) was significantly higher than that of CRISPR 2 (74.4\%) $(p<0.05)$. On the other hand, no significant differences between the companies were observed. 
Table 1. Distribution of virulence genes in E. coli isolated from bulk tank milk.

\begin{tabular}{|c|c|c|c|c|}
\hline \multirow{2}{*}{$\begin{array}{l}\text { Virulence } \\
\text { Genes }{ }^{1}\end{array}$} & \multicolumn{4}{|c|}{ No (\%) of Isolates Included by Company } \\
\hline & $\mathrm{A}\left(n^{2}=38\right)$ & B $(n=42)$ & $C(n=103)$ & Total $(n=183)$ \\
\hline fimH & $36(94.7) \mathrm{a}$ & $41(100.0)_{a}$ & $71(69.0)_{b}$ & $148(80.9)^{\mathrm{A}}$ \\
\hline iss & $27(71.1) \mathrm{a}$ & $14(34.1)_{\mathrm{b}}$ & $29(28.2)_{b}$ & $70(38.3)^{\mathrm{B}}$ \\
\hline traT & $21(55.3) \mathrm{a}$ & $12(29.3)_{b}$ & $16(15.5)_{b}$ & $49(26.8) \mathrm{B}, \mathrm{C}$ \\
\hline ompT & $10(26.3)$ & $14(34.1)$ & $23(22.3)$ & $47(25.7)^{B, C}$ \\
\hline$a f a / d r a B C$ & $6(15.8)$ & $11(26.8)$ & $27(26.2)$ & $44(24.0) \mathrm{B}, \mathrm{C}$ \\
\hline univenf & $6(15.8)$ & $15(36.6)$ & $19(18.4)$ & $40(21.9)$ B,C \\
\hline iroN E. coli & $5(13.2)$ & $8(19.5)$ & $12(11.7)$ & $25(13.7)$ C,D \\
\hline kpsMT K5 & $2(5.3) a$ & $7(17.1)_{a}$ & $4(3.9)_{b}$ & $13(7.1)^{\mathrm{D}, \mathrm{E}}$ \\
\hline fyuA & $5(13.2)$ & $3(7.3)$ & $4(3.9)$ & 12 (6.6) $\mathrm{D}, \mathrm{E}$ \\
\hline$s f a S$ & $3(7.9)$ & $1(2.4)$ & $8(7.8)$ & $12(6.6)^{\mathrm{D}, \mathrm{E}}$ \\
\hline bmaE & $0(0.0)$ & $0(0.0)$ & $9(8.7)$ & $9(4.9) \mathrm{D}, \mathrm{E}$ \\
\hline cnf1 & $2(5.3)$ & $0(0.0)$ & $3(2.9)$ & $5(2.7)^{\mathrm{E}}$ \\
\hline$c d t$ & $0(0.0)$ & $1(2.4)$ & $3(2.9)$ & $4(2.2)^{\mathrm{E}}$ \\
\hline hlyA & $1(2.6)$ & $1(2.4)$ & $1(1.0)$ & $3(1.6)^{\mathrm{E}}$ \\
\hline$c d t B$ & $0(0.0)$ & $0(0.0)$ & $2(1.9)$ & $2(1.1)^{\mathrm{E}}$ \\
\hline iut $A$ & $1(2.6)$ & $0(0.0)$ & $0(0.0)$ & $1(0.5)^{\mathrm{E}}$ \\
\hline pap G allele 3 & $1(2.6)$ & $0(0.0)$ & $0(0.0)$ & $1(0.5)^{\mathrm{E}}$ \\
\hline kpsMT II & $1(2.6)$ & $0(0.0)$ & $0(0.0)$ & $1(0.5)^{\mathrm{E}}$ \\
\hline
\end{tabular}

${ }^{1}$ PAI, cvaC, focG, ibeA, ireA, kpsMT K1, kpsMT III, nfaE, papAH, papC, papEF, papG allele 1, papG allele 2, rfc and sfa/focDE genes were not detected in any of the isolates. ${ }^{2} n=$ No. of $E$. coli isolated from each company. Values with different subscript letters represent significant differences among companies, while superscript letters represent significant differences in total $(p<0.05)$.

Table 2. Distribution of phylogenetic groups and CRISPR loci of 164 E. coli possessing virulence genes isolated from bulk tank milk.

\begin{tabular}{|c|c|c|c|c|}
\hline \multirow{2}{*}{ Groups } & \multicolumn{4}{|c|}{ No (\%) of Isolates Included by Company } \\
\hline & $\mathrm{A}\left(n^{1}=38\right)$ & B $(n=41)$ & $C(n=85)$ & Total $(n=164)$ \\
\hline \multicolumn{5}{|c|}{ Phylogenetic groups } \\
\hline $\mathrm{A}$ & $3(7.9)_{b}$ & $13(31.7)_{\mathrm{a}}$ & $17(20.0)_{a, b}$ & $33(20.1)^{\mathrm{B}}$ \\
\hline B1 & $26(68.4)$ & $20(48.8)$ & $59(69.4)$ & $105(64.0)^{\mathrm{A}}$ \\
\hline B2 & $0(0.0)$ & $0(0.0)$ & $0(0.0)$ & $0(0.0)^{\mathrm{D}}$ \\
\hline $\mathrm{C}$ & $1(2.6)$ & $5(12.2)$ & $6(7.1)$ & $12(7.3)^{C}$ \\
\hline $\mathrm{D}$ & $8(21.1) \mathrm{a}$ & $3(7.3) a, b$ & $3(3.5)_{b}$ & $14(8.5)^{C}$ \\
\hline $\mathrm{E}$ & $0(0.0)$ & $0(0.0)$ & $0(0.0)$ & $0(0.0)^{\mathrm{D}}$ \\
\hline $\mathrm{F}$ & $0(0.0)$ & $0(0.0)$ & $0(0.0)$ & $0(0.0)^{\mathrm{D}}$ \\
\hline \multicolumn{5}{|c|}{ CRISPR loci } \\
\hline CRISPR 1 & 37 (97.4) & $38(92.7)$ & $82(96.5)$ & $157(95.7)^{\mathrm{A}}$ \\
\hline CRISPR 2 & $33(86.8)$ & $31(75.6)$ & $58(68.2)$ & $122(74.4)^{\mathrm{B}}$ \\
\hline CRISPR 3 & $0(0.0)$ & $0(0.0)$ & $0(0.0)$ & $0(0.0)^{C}$ \\
\hline CRISPR 4 & $0(0.0)$ & $0(0.0)$ & $0(0.0)$ & $0(0.0)^{C}$ \\
\hline
\end{tabular}

${ }^{1} n=$ No. of $E$. coli isolated from each company. Values with different subscript letters represent significant differences among companies, while superscript letters represent significant differences in total $(p<0.05)$.

\subsection{Distribution of CRISPR 1 and CRISPR 2 by Phylogenetic Group}

The association of CRISPR 1 and CRISPR 2 with phylogenetic groups of $E$. coli is shown in Figure 1. The prevalence of CRISPR 1 by phylogenetic groups ranged from $75.0 \%$ to $98.1 \%$, whereas that of CRISPR 2 ranged from $60.6 \%$ to $92.9 \%$. Interestingly, the distribution of CRISPR 1 and CRISPR 2 in the phylogenetic groups showed significant differences. The distribution of CRISPR 1 was significantly higher in groups A and B1 than that of CRISPR 2 $(p<0.05)$. The prevalence of CRISPR 1 and CRISPR 2 showed no significant differences in groups $\mathrm{C}$ and $\mathrm{D}$. 


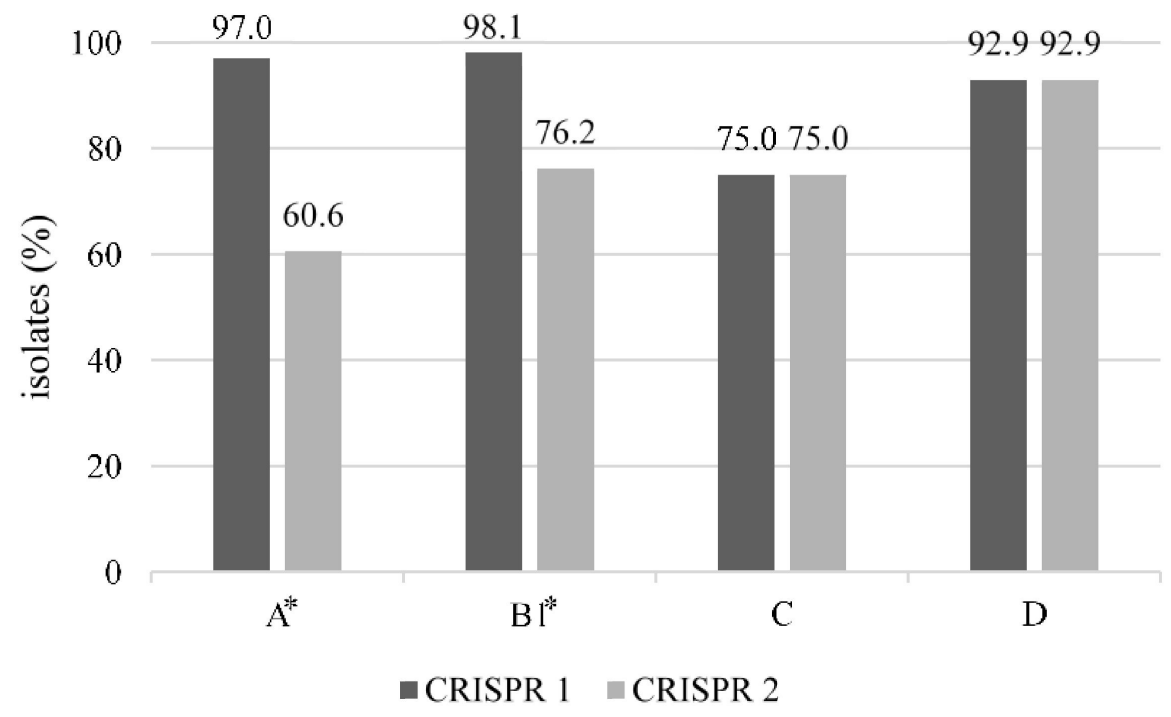

Figure 1. Distribution of CRISPR 1 and CRISPR 2 by phylogenetic group in 164 E. coli possessing virulence genes, isolated from bulk tank milk. The asterisk indicates that there were significant differences between CRISPR 1 and CRISPR $2(p<0.05)$.

\subsection{Distribution of CRISPR 1 and CRISPR 2 by Virulence Genes}

The association of CRISPR 1 and CRISPR 2 with six common virulence genes of E. coli is shown in Figure 2. The prevalence of CRISPR 1 by virulence gene ranged from $91.8 \%$ to $100 \%$, whereas that of CRISPR 2 ranged from $57.5 \%$ to $93.9 \%$. The distribution of CRISPR loci also showed differences by virulence gene. The distribution of CRISPR 1 was significantly higher in fimH, omp , afa/draBC, and univcnf genes than that of CRISPR 2 $(p<0.05)$. Moreover, iss and traT genes showed equally high distributions, and no significant differences between CRISPR 1 and CRISPR 2.

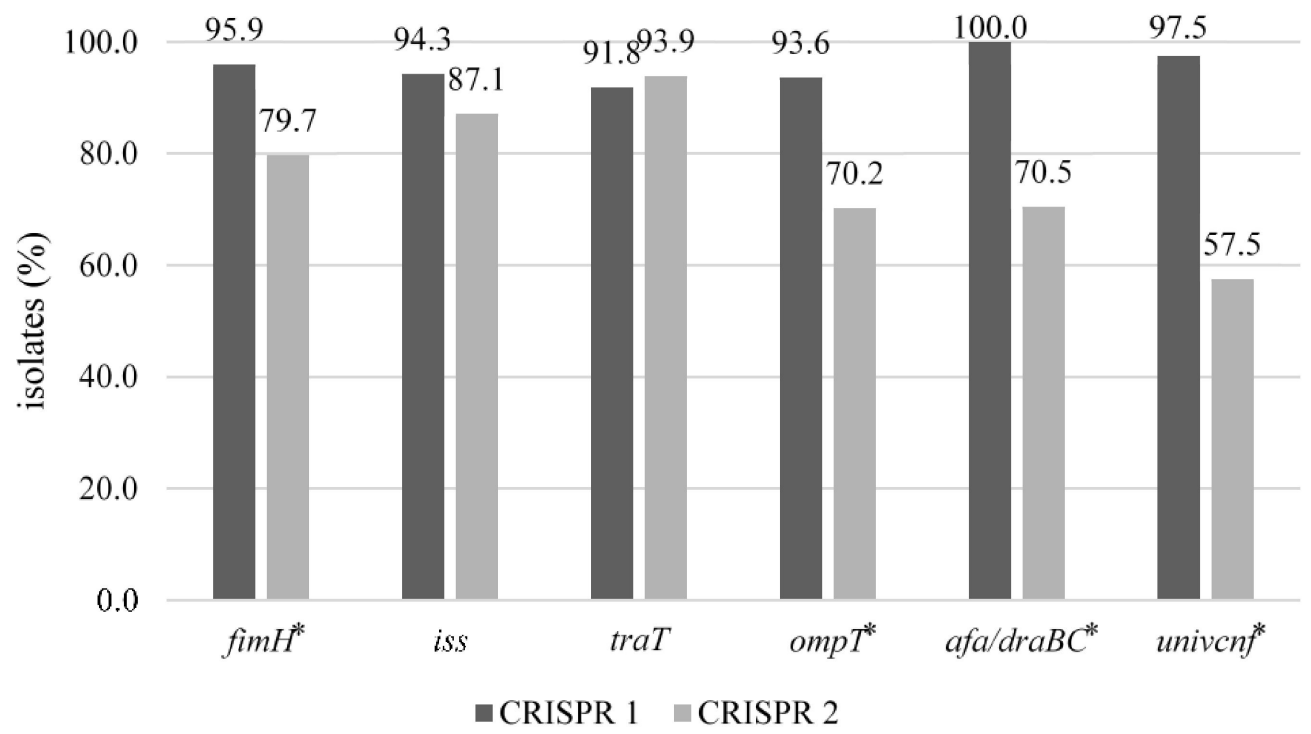

Figure 2. Distribution of CRISPR1 and CRISPR2 by virulence gene in 164 E. coli possessing virulence genes, isolated from bulk tank milk. The asterisk indicates that there were significant differences between CRISPR 1 and CRISPR $2(p<0.05)$.

\subsection{CRISPR-Based Typing of Virulence Gene-Carrying Isolates}

The distribution of ESTs by six common virulence genes of E. coli is presented in Table 3. A total of 26 ESTs were assigned based on the distribution of spacers from CRISPR 
1 and CRISPR 2. The most prevalent EST was EST 22 (45.1\%), followed by EST 4 (23.2\%), EST $16(20.1 \%)$, EST 25 (19.5\%), and EST 24 (18.3\%). Interestingly, four genes, fimH, ompT, afa/draBC, and univcnf, had a significantly higher prevalence in both EST 4 and EST 22, while iss and traT genes had a significantly lower prevalence than the other four genes in both EST 4 and EST $22(p<0.05)$.

Table 3. CRISPR-based typing by virulence gene in 164 E. coli possessing virulence genes, isolated from bulk tank milk.

\begin{tabular}{|c|c|c|c|c|c|c|c|}
\hline \multirow[b]{2}{*}{ E. coli Sequence Types } & \multicolumn{7}{|c|}{ No (\%) of Isolates with Virulence Genes } \\
\hline & $\begin{array}{c}f i m H \\
\left(n^{1}=148\right)\end{array}$ & $\begin{array}{c}\text { iss } \\
(n=70)\end{array}$ & $\begin{array}{c}\operatorname{traT} \\
(n=49)\end{array}$ & $\begin{array}{c}\text { ompT } \\
(n=47)\end{array}$ & $\begin{array}{c}a f a / d a r B C \\
(n=44)\end{array}$ & $\begin{array}{l}\text { univcnf } \\
(n=40)\end{array}$ & $\begin{array}{c}\text { Total } \\
(n=164)\end{array}$ \\
\hline EST 1 & $0(0.0)_{b}{ }^{B}$ & $2(2.9)_{a, b}$ & $0(0.0)_{b}$ & $5(10.6)_{a, b}{ }^{A}$ & $3(6.8)_{a, b} B$ & $9(22.5) a_{a}^{A}$ & $19(11.6)^{C, D}$ \\
\hline EST 2 & $2(1.4)^{\mathrm{B}}$ & $1(1.4)$ & $0(0.0)$ & $1(2.1)^{\mathrm{B}}$ & $0(0.0)^{B}$ & $1(2.5)^{\mathrm{B}}$ & $5(3.0)^{\mathrm{E}, \mathrm{F}}$ \\
\hline EST 3 & $3(2.0)^{\mathrm{B}}$ & $2(2.9)$ & $2(4.1)$ & $1(2.1)^{\mathrm{B}}$ & $0(0.0)^{\mathrm{B}}$ & $0(0.0)^{\mathrm{B}}$ & $8(4.9)^{\mathrm{E}, \mathrm{F}}$ \\
\hline EST 4 & $16(10.8) \mathrm{a}^{\mathrm{A}}$ & $2(2.9)_{b, c}$ & $0(0.0)_{\mathrm{c}}$ & $6(12.8)_{a, b} \mathrm{~A}$ & $9(20.5)_{a, b} \mathrm{~A}$ & $5(12.5)_{a, b} \mathrm{~A}$ & $38(23.2)^{\mathrm{B}}$ \\
\hline EST 5 & $3(2.0)^{\mathrm{B}}$ & $1(1.4)$ & $0(0.0)$ & $1(2.1)^{\mathrm{B}}$ & $0(0.0)^{B}$ & $1(2.5)^{\mathrm{B}}$ & $6(3.7) \mathrm{E}, \mathrm{F}$ \\
\hline EST 6 & $2(1.4)^{\mathrm{B}}$ & $0(0.0)$ & $0(0.0)$ & $0(0.0)^{\mathrm{B}}$ & $0(0.0)^{\mathrm{B}}$ & $0(0.0)^{\mathrm{B}}$ & $2(1.2)^{\mathrm{F}}$ \\
\hline EST 7 & $2(1.4)^{\mathrm{B}}$ & $0(0.0)$ & $1(2.0)$ & $0(0.0)^{\mathrm{B}}$ & $1(2.3)^{\mathrm{B}}$ & $0(0.0)^{\mathrm{B}}$ & $4(2.4)^{\mathrm{F}}$ \\
\hline EST 8 & $3(2.0)^{B}$ & $2(2.9)$ & $3(6.1)$ & $2(4.3)^{\mathrm{B}}$ & $2(4.5)^{\mathrm{B}}$ & $0(0.0)^{\mathrm{B}}$ & $12(7.3)^{\mathrm{D}, \mathrm{E}}$ \\
\hline EST 9 & $3(2.0)^{\mathrm{B}}$ & $2(2.9)$ & $1(2.0)$ & $1(2.1)^{\mathrm{B}}$ & $1(2.3)^{B}$ & $0(0.0)^{\text {В }}$ & $8(4.9) \mathrm{E}, \mathrm{F}$ \\
\hline EST 10 & $7(4.7){ }_{a}{ }^{\mathrm{B}}$ & $4(5.7)_{\mathrm{a}, \mathrm{b}}$ & $2(4.1)_{\mathrm{a}, \mathrm{b}}$ & $3(6.4)_{a, b}{ }^{B}$ & $0(0.0)_{b}{ }^{B}$ & $2(5.0)_{a, b} B$ & $18(11.0)^{C, D}$ \\
\hline EST 11 & $3(2.0)^{\mathrm{B}}$ & $3(4.3)$ & $2(4.1)$ & $0(0.0)^{\mathrm{B}}$ & $0(0.0)^{\mathrm{B}}$ & $0(0.0)^{\mathrm{B}}$ & $8(4.9)^{\mathrm{E}, \mathrm{F}}$ \\
\hline EST 12 & $1(0.7)^{B}$ & $0(0.0)$ & $1(2.0)$ & $0(0.0)^{\mathrm{B}}$ & $1(2.3)^{B}$ & $0(0.0)^{B}$ & $3(1.8)^{\mathrm{F}}$ \\
\hline EST 13 & $7(4.7){ }_{a}^{\mathrm{B}}$ & $5(7.1)_{a, b}$ & $1(2.0)_{a, b}$ & $1(2.1)_{a b}$ в & $1(2.3)_{a b}$ в & $0(0.0)_{b}{ }^{\mathrm{B}}$ & $15(9.1)^{\mathrm{D}, \mathrm{E}}$ \\
\hline EST 14 & $8(5.4)_{a}^{\mathrm{B}}$ & $6(8.6)_{a, b}$ & $8(16.3)_{a}$ & $0(0.0)_{\mathrm{b}}^{\mathrm{B}}$ & $2(4.5)_{a, b}{ }^{2}$ & $1(2.5)_{a, b} B$ & $25(15.2)^{C}$ \\
\hline EST 15 & $2(1.4)^{\mathrm{B}}$ & $2(2.9)$ & $1(2.0)$ & $0(0.0)^{\mathrm{B}}$ & $2(4.5)^{\mathrm{B}}$ & $\begin{array}{r}1(2 . J) \mathrm{a}, \mathrm{b} \\
0(0.0)^{\mathrm{B}}\end{array}$ & $7(4.3)^{\mathrm{E}, \mathrm{F}}$ \\
\hline EST 16 & $8(5.4)^{\mathrm{B}}$ & $7(10.0)$ & $8(16.3)$ & $5(10.6)^{A}$ & $4(9.1)^{\mathrm{B}}$ & $1(2.5)^{B}$ & $33(20.1)^{B}$ \\
\hline EST 17 & $3(2.0)^{B}$ & $1(1.4)$ & $2(4.1)$ & $0(0.0)^{\mathrm{B}}$ & $0(0.0)^{\mathrm{B}}$ & $0(0.0)^{\mathrm{B}}$ & $6(3.7)^{\mathrm{E}, \mathrm{F}}$ \\
\hline EST 18 & $3(2.0)^{\mathrm{B}}$ & $0(0.0)$ & $0(0.0)$ & $0(0.0)^{\mathrm{B}}$ & $0(0.0)^{\mathrm{B}}$ & $0(0.0)^{\mathrm{B}}$ & $3(1.8)^{F}$ \\
\hline EST 19 & $3(2.0)^{B}$ & $3(4.3)$ & $0(0.0)$ & $0(0.0)^{\mathrm{B}}$ & $0(0.0)^{\mathrm{B}}$ & $0(0.0)^{\mathrm{B}}$ & $6(3.7)^{\mathrm{E}, \mathrm{F}}$ \\
\hline EST 20 & $3(2.0)^{\mathrm{B}}$ & $0(0.0)$ & $3(6.1)$ & $0(0.0)^{\mathrm{B}}$ & $0(0.0)^{\mathrm{B}}$ & $0(0.0)^{\mathrm{B}}$ & $6(3.7)^{\mathrm{E}, \mathrm{F}}$ \\
\hline EST 21 & $2(1.4)^{B}$ & $2(2.9)$ & $0(0.0)$ & $1(2.1)^{B}$ & $0(0.0)^{B}$ & $2(5.0)^{B}$ & $7(4.3)^{\mathrm{E}, \mathrm{F}}$ \\
\hline EST 22 & $33(22.3) a^{A}$ & $9(12.9)_{b}$ & $0(0.0)_{\mathrm{c}}$ & $10(21.3)_{b}{ }^{A}$ & $13(29.5)_{b}{ }^{A}$ & $9(22.5)_{\mathrm{b}} \mathrm{A}$ & $74(45.1)^{\mathrm{A}}$ \\
\hline EST 23 & $7(4.7) \mathrm{a}^{\mathrm{B}}$ & $2(2.9)_{a, b}$ & $4(8.2)_{a, b}$ & $1(2.1)_{a, b}{ }^{3}$ & $1(2.3)_{a, b} \mathrm{~B}$ & $0(0.0){ }^{B}$ & $15(9.1)^{\mathrm{D}, \mathrm{E}}$ \\
\hline EST 24 & $10(6.8)_{\mathrm{a}} \mathrm{B}$ & $7(10.0)_{a, b}$ & $1(2.0)_{\mathrm{b}}$ & $5(10.6){ }_{a, b}^{a, b} \mathrm{~A}$ & $0(0.0)_{b}{ }_{b}, b$ & $7(17.5)_{a, b} \mathrm{~A}$ & $30(18.3)^{B, C}$ \\
\hline EST 25 & $11(7.4) \mathrm{a}^{\mathrm{A}}$ & $5(7.1)$ & $8(16.3)$ & $3(6.4),{ }^{B}$ & $4(9.1)$ B & $1(2.5){ }_{b}$ & $32(19.5)^{B, C}$ \\
\hline EST 26 & $3(2.0)^{\mathrm{B}}$ & $2(2.9)$ & $1(2.0)$ & $1(2.1)^{B}$ & $0(0.0)^{\mathrm{B}}$ & $1(2.5)^{\mathrm{B}}$ & $8(4.9)^{\mathrm{E}, \mathrm{F}}$ \\
\hline
\end{tabular}

\subsection{Protospacer Match from Spacer Sequences}

The protospacers matching plasmids and phages, and sequences are presented in Table 4. Seven and one protospacers were found in CRISPR 1 and CRISPR 2, respectively. Interestingly, protospacer 163, which is associated with virulence due to the tail-associated lysozyme of bacteriophage, had the highest prevalence (20.4\%), and it only existed in EST 4 and EST22 (Supplementary Figure S1). Moreover, other protospacers were concerned with the protection of bacteria against the host immune system, such as toll/interleukin-1 receptor domain-containing protein $(0.6 \%)$, or gene regulation, such as DNA-binding protein $(18.5 \%)$, DNA-cytosine methyltransferase $(7.0 \%)$, and $\operatorname{darB}$, helicase $(0.6 \%)$. However, protospacer $117(7.6 \%)$ and protospacer $47(0.8 \%)$ in CRISPR 1 and CRISPR 2 loci, respectively, were domains of unknown function. 
Table 4. Protospacers matching plasmids and phages, and spacer sequences in 164 E. coli possessing virulence genes, isolated from bulk tank milk.

\begin{tabular}{|c|c|c|c|c|}
\hline CRISPR Array & Name of Protospacer & Sequences $\left(5^{\prime}\right.$ to $\left.3^{\prime}\right)$ & No. (\%) of Isolates & Protospacer Match \\
\hline \multirow[t]{7}{*}{ CRISPR 1} & 1 & $\begin{array}{l}\text { ACATGAATGTCGGTTCAGACCGTGTTTTTACC } \\
\text { TGTACTTACAGCCAAGTCTGGCACAAAAATGG }\end{array}$ & $29(18.5)$ & DNA-binding protein \\
\hline & 78 & CССTCACACCGATTCGCCAAACGGTGGAGAAG & $1(0.6)$ & $\begin{array}{l}\text { toll/interleukin- } 1 \text { receptor } \\
\text { domain-containing protein }\end{array}$ \\
\hline & 81 & $\begin{array}{l}\text { GGGAGTGTGGCTAAGCGGTTTGCCACCTCTTC } \\
\text { TTTTGCTGACACCGGCAATACTGAACGGCTGG } \\
\text { AAAACGACTGTGGCCGTTATGACTTGCCGACC }\end{array}$ & $11(7.0)$ & DNA-cytosine methyltransferase \\
\hline & 107 & $\begin{array}{l}\text { GCTGGTGGCGCGGGCAAACGGAACAATCCCGC } \\
\text { CGACCACCGCGCCCGTTTGCCTTGTTAGGGCG }\end{array}$ & $1(0.6)$ & darB, helicase \\
\hline & 117 & $\begin{array}{l}\text { AAACAGATTGTTCGTTTTCCCCATATTCATGA } \\
\text { TTTGTCTAACAAGCAAAAGGGGTATAAGTACT }\end{array}$ & $12(7.6)$ & DUF1380 domain-containing protein \\
\hline & 162 & AGTATTAACTGCGGTGGCAGTGAGGCCAATAG & $1(0.6)$ & $\begin{array}{l}\text { Head decoration protein, } \\
\text { Viral protein }\end{array}$ \\
\hline & 163 & $\begin{array}{l}\text { TCATAATTGACGCCACCGTCACTCCGGTTATC } \\
\text { GTTGCCCCCCAAAATCATTAAATCCCCGGCGG } \\
\text { CAACGGGGGGTTTTAGTAATTTAGGGGCCGCC }\end{array}$ & $32(20.4)$ & tail associated lysozyme \\
\hline CRISPR 2 & 47 & $\begin{array}{l}\text { GAAAAATGCATACGATTCGAGCACCAGTTTGGC } \\
\text { CTTTTTACGTATGCTAAGCTCGTGGTCAAACCG }\end{array}$ & $1(0.8)$ & DUF1281 domain-containing protein \\
\hline
\end{tabular}

\section{Discussion}

Mastitis caused by $E$. coli is one of the most frequent diseases in dairy cattle resulting from environmental infection, and it is usually characterized by changes in milk composition and quality [1,2]. Although the relationship between virulence factors on bovine mastitis caused by E. coli and its clinical severity has not been fully elucidated, many studies have reported the influence of virulence factors on the establishment of clinically severe infections [6,31]. In this study, 18 out of 33 virulence genes associated with ExPEC were detected, and $89.6 \%$ of isolates from normal bulk tank milk carried one or more virulence genes. In particular, fim $H$, which is associated with the virulence factor adhesin, was detected the most often (80.9\%). Guerra et al. (2020) [32] and Zhang et al. (2018) [33] also reported a $100 \%$ and $89.9 \%$ prevalence of fimH, respectively, indicating its ubiquity among mastitis-causing $\mathrm{E}$. coli isolates. The $\mathrm{fimH}$ gene is a bacterial adhesin that helps E. coli bind to host cells and their receptors, and plays a crucial role in causing bovine mastitis by colonizing the mammary glands, resembling the pathogenesis of urinary tract infections $[31,34,35]$. Other virulence genes of adhesin, such as afa/draBC, sfaS, bmaE, and pap G allele 3, were also detected in this study. The prevalence rates of these genes varied from $0.5 \%$ to $24.0 \%$, but the presence of these adhesins also implies the facilitated attachment of bacteria onto host cells, helping the colonization of the region and increasing the possibility of mastitis [6,31].

Toxins encoded by virulence genes, such as univcnf, cnf1, $c d t, h l y A$, and $c d t B$, are considered essential in the pathogenesis of mastitis following colonization via adhesins. In this study, the most prevalent toxin gene was univcnf $(21.9 \%)$, while the prevalence of other toxin genes ranged from $1.1 \%$ to $2.7 \%$. Lehtolainen et al. (2003) [36] reported that cytotoxic necrotizing factors (CNF), encoded by univcnf, $c n f 1$, and $\operatorname{cnf} 2$, are significantly associated with the persistence of mastitis. Moreover, the potential of CNFs to cause tissue damage or mediate bacteremia can lead to acute mastitis with severe systemic symptoms [37]. Therefore, if whole milk was derived from clinical mastitis rather than from a normal bulk tank, a higher prevalence may be confirmed.

Although the prevalence of the genes iss and traT, which are related to serum survival, was $38.3 \%$ and $26.8 \%$, respectively, in this study, several reports have described the absence of a correlation between the presence of these genes and the pathogenicity of mastitis $[31,38,39]$. Therefore, it is difficult to predict whether the presence of iss and traT genes in E. coli from bulk tank milk may increase the risk of mastitis.

Phylogenetic analysis is increasingly being used as a modern method of determining virulence potential [40]. In this study, the phylogenetic group B1 (64.0\%) was the most prevalent, followed by A (20.1\%). On the other hand, phylogroups B2 and D, which were reported as highly virulent phylogroups regarding ExPEC [40,41], were detected at $0.0 \%$ and $8.5 \%$ prevalence, respectively. This result is in accordance with those of previous 
studies that phylogroups B1 and A were the most common groups in normal and mastitis milk samples, while phylogroups D and B2 were rarely detected [42]. According to previous studies, mastitis-causing E. coli isolates may be related to commensal isolates attaining virulence genes, causing infection in hosts with compromised immune systems $[43,44]$.

E. coli contains four CRISPR loci: CRISPR 1, 2, 3 and 4; these are classified as either Type I-E (CRISPR 1 and 2) or Type I-F (CRISPR 3 and 4), depending on the presence of the associated cas genes [45]. In this study, 161 (98.2\%) of 164 isolates possessing virulence genes were identified to possess CRISPR 1 and/or CRISPR 2, which comprise highly conserved direct repeat sequences with variable spacer sequences [22]. Meanwhile, CRISPR 3 and 4 loci, which possess a lower spacer distribution, were not detected. It was reported that CRISPR 1 and/or 2 loci have been preserved and stationary within E. coli over a long period [46], whereas CRISPR 3 and 4 loci are a recent creation [22]. Moreover, the hypervariability of CRISPR loci can be applied in phylogenetic analysis, as in previous reports [21,47]. In particular, Touchon et al. (2011) [22] reported that only the phylogenetic group B2 possessed CRISPR 4, implying that the absence of CRISPR 3 and 4 in this study could be linked to the absence of the phylogenetic group B2. Moreover, the absence of a significant difference in the distributions of CRISPR 1 and 2 in the phylogenetic groups C and $\mathrm{D}$ is also suggested to be linked with CRISPR loci and phylogeny.

Because both virulence genes and spacers of CRISPR are acquired by horizontal gene transfer via plasmids and phages $[48,49]$, isolates with different virulence genes can have different distributions in CRISPR content, resulting in different ESTs. In this study, the distributions of EST 4 and EST 22 were significantly higher in isolates harboring fim $H$, ompT, $a f a / d r a B C$, and univonf, which play a crucial role in MPEC, compared to isolates carrying the genes iss and traT, which lack a role in pathogenicity. Therefore, these results suggest that the distribution of spacers may be reflected by the presence of virulence genes, as previously reported [24,50].

The CRISPR system of $E$. coli also functions as a regulatory mechanism and immune system of bacteria [22,51-54]. In this study, three (DNA-cytosine methyltransferase, DNAbinding protein, and helicase) of eight protospacers were associated with gene regulation. Bozic et al. (2019) [55] reported that CRISPR I-E (CRISPR 1 and 2) targets bacterial chromosomes, suggesting its major role in the regulation of endogenous genes. Moreover, protospacer 163, which is linked with bacteriophage tail-associated protein, is homologous to the Type VI secretion apparatus [56], which is associated with the increased virulence of many pathogens [57]. Interestingly, in this study, protospacer 163 was only detected in EST 4 and EST 22, which are ESTs with a significantly higher prevalence in isolates carrying four virulence genes (fimH, ompT, afa/draBC, and univcnf).

\section{Conclusions}

In conclusion, the results of protospacer distribution suggest that CRISPR I-E is linked with gene regulation and pathogenicity in E. coli. Moreover, the CRISPR sequence-typing approach helped to clarify and trace virulence potential, by showing significant differences in prevalence based on different virulence genes.

Supplementary Materials: The following supporting information can be downloaded at: https: / / www.mdpi.com/article/10.3390/ani12040503/s1, Figure S1: Grouping of 164 isolates into Escherichia sequence types (ESTs) according to spacer contents; Table S1: Names and sequences of all spacers in each CRISPR locus identified in this study.

Author Contributions: Conceptualization, H.-J.K. and Y.-J.L.; data curation, H.-J.K.; formal analysis, H.-J.K.; investigation, H.-J.K.; methodology, H.-J.K. and Y.-J.L.; software, H.-J.K.; supervision, Y.-J.L.; writing-original draft, H.-J.K.; writing—review and editing, Y.-J.L. All authors have read and agreed to the published version of the manuscript.

Funding: This research received no external funding.

Institutional Review Board Statement: Not applicable. 
Informed Consent Statement: Not applicable.

Data Availability Statement: Not applicable.

Conflicts of Interest: The authors declare no conflict of interest. The funders had no role in the design of the study; in the collection, analyses, or interpretation of the data; in the writing of the manuscript; or in the decision to publish the results.

\section{References}

1. Kaper, J.B.; Nataro, J.P.; Mobley, H.L.T. Pathogenic Escherichia coli. Nat. Rev. Microbiol. 2004, 2, 123-140. [CrossRef] [PubMed]

2. Petzl, W.; Zerbe, H.; Günther, J.; Seyfert, H.-M.; Hussen, J.; Schuberth, H.-J. Pathogen-Specific Responses in the Bovine Udder. Models and Immunoprophylactic Concepts. Res. Vet. Sci. 2018, 116, 55-61. [CrossRef] [PubMed]

3. Guerra, S.T.; Dalanezi, F.M.; de Paula, C.L.; Hernandes, R.T.; Pantoja, J.C.F.; Listoni, F.J.P.; Langoni, H.; Ribeiro, M.G. Putative Virulence Factors of Extra-Intestinal Escherichia coli Isolated from Bovine Mastitis with Different Clinical Scores. Lett. Appl. Microbiol. 2019, 68, 403-408. [CrossRef] [PubMed]

4. Olson, M.A.; Grimsrud, A.; Richards, A.C.; Mulvey, M.A.; Wilson, E.; Erickson, D.L. Bile Salts Regulate Zinc Uptake and Capsule Synthesis in a Mastitis-Associated Extraintestinal Pathogenic Escherichia coli Strain. Infect. Immun. 2021, 89, e00357-21. [CrossRef]

5. Aslam, N.; Khan, S.-U.-H.; Usman, T.; Ali, T. Phylogenetic Genotyping, Virulence Genes and Antimicrobial Susceptibility of Escherichia coli Isolates from Cases of Bovine Mastitis. J. Dairy Res. 2021, 88, 78-79. [CrossRef]

6. Fernandes, J.B.C.; Zanardo, L.G.; Galvão, N.N.; Carvalho, I.A.; Nero, L.A.; Moreira, M.A.S. Escherichia coli from Clinical Mastitis: Serotypes and Virulence Factors. J. Vet. Diagn. Investig. 2011, 23, 1146-1152. [CrossRef]

7. Tenaillon, O.; Skurnik, D.; Picard, B.; Denamur, E. The Population Genetics of Commensal Escherichia coli. Nat. Rev. Microbiol. 2010, 8, 207-217. [CrossRef]

8. Alfinete, N.W.; Bolukaoto, J.Y.; Heine, L.; Potgieter, N.; Barnard, T.G. Virulence and Phylogenetic Analysis of Enteric Pathogenic Escherichia coli Isolated from Children with Diarrhoea in South Africa. Int. J. Infect. Dis. 2022, 114, 226-232. [CrossRef]

9. Clermont, O.; Christenson, J.K.; Denamur, E.; Gordon, D.M. The Clermont Escherichia coli Phylo-Typing Method Revisited: Improvement of Specificity and Detection of New Phylo-Groups. Environ. Microbiol. Rep. 2013, 5, 58-65. [CrossRef]

10. Mora, A.; López, C.; Dabhi, G.; Blanco, M.; Blanco, J.E.; Alonso, M.P.; Herrera, A.; Mamani, R.; Bonacorsi, S.; Moulin-Schouleur, M.; et al. Extraintestinal Pathogenic Escherichia coli O1:K1:H7/NM from Human and Avian Origin: Detection of Clonal Groups B2 ST95 and D ST59 with Different Host Distribution. BMC Microbiol. 2009, 9, 132. [CrossRef]

11. Logue, C.M.; Wannemuehler, Y.; Nicholson, B.A.; Doetkott, C.; Barbieri, N.L.; Nolan, L.K. Comparative Analysis of Phylogenetic Assignment of Human and Avian ExPEC and Fecal Commensal Escherichia coli Using the (Previous and Revised) Clermont Phylogenetic Typing Methods and Its Impact on Avian Pathogenic Escherichia coli (APEC) Classification. Front. Microbiol. 2017,8 , 283. [CrossRef] [PubMed]

12. Leimbach, A.; Poehlein, A.; Vollmers, J.; Görlich, D.; Daniel, R.; Dobrindt, U. No Evidence for a Bovine Mastitis Escherichia coli Pathotype. BMC Genom. 2017, 18, 359. [CrossRef] [PubMed]

13. Bag, M.A.S.; Khan, M.S.R.; Sami, M.D.H.; Begum, F.; Islam, M.S.; Rahman, M.M.; Rahman, M.T.; Hassan, J. Virulence Determinants and Antimicrobial Resistance of E. coli Isolated from Bovine Clinical Mastitis in Some Selected Dairy Farms of Bangladesh. Saudi J. Biol. Sci. 2021, 28, 6317-6323. [CrossRef]

14. Jung, D.; Park, S.; Ruffini, J.; Dussault, F.; Dufour, S.; Ronholm, J. Comparative Genomic Analysis of Escherichia coli Isolates from Cases of Bovine Clinical Mastitis Identifies Nine Specific Pathotype Marker Genes. Microb. Genom. 2021, 7, 8. [CrossRef]

15. Mojica, F.J.M.; Díez-Villaseñor, C.; García-Martínez, J.; Soria, E. Intervening Sequences of Regularly Spaced Prokaryotic Repeats Derive from Foreign Genetic Elements. J. Mol. Evol. 2005, 60, 174-182. [CrossRef] [PubMed]

16. Barrangou, R.; Fremaux, C.; Deveau, H.; Richards, M.; Boyaval, P.; Moineau, S.; Romero, D.A.; Horvath, P. CRISPR Provides Acquired Resistance against Viruses in Prokaryotes. Science 2007, 315, 1709-1712. [CrossRef]

17. Hatoum-Aslan, A.; Marraffini, L.A. Impact of CRISPR Immunity on the Emergence and Virulence of Bacterial Pathogens. Curr. Opin. Microbiol. 2014, 17, 82-90. [CrossRef]

18. Bonomo, M.E.; Deem, M.W. The Physicist's Guide to One of Biotechnology's Hottest New Topics: CRISPR-Cas. Phys. Biol. 2018, 15, 041002. [CrossRef]

19. Kim, K.; Yoon, S.; Kim, Y.B.; Lee, Y.J. Virulence Variation of Salmonella gallinarum Isolates through SpvB by CRISPR Sequence Subtyping, 2014 to 2018. Animals 2020, 10, 2346. [CrossRef] [PubMed]

20. Díez-Villaseñor, C.; Almendros, C.; García-Martínez, J.; Mojica, F.J.M. Diversity of CRISPR Loci in Escherichia coli. Microbiology 2010, 156, 1351-1361. [CrossRef]

21. Touchon, M.; Rocha, E.P.C. The Small, Slow and Specialized CRISPR and Anti-CRISPR of Escherichia and Salmonella. PLoS ONE 2010, 5, e11126. [CrossRef]

22. Touchon, M.; Charpentier, S.; Clermont, O.; Rocha, E.P.C.; Denamur, E.; Branger, C. CRISPR Distribution within the Escherichia coli Species Is Not Suggestive of Immunity-Associated Diversifying Selection. J. Bacteriol. 2011, 193, 2460-2467. [CrossRef] [PubMed]

23. Yin, S.; Jensen, M.A.; Bai, J.; DebRoy, C.; Barrangou, R.; Dudley, E.G. The Evolutionary Divergence of Shiga Toxin-Producing Escherichia coli Is Reflected in Clustered Regularly Interspaced Short Palindromic Repeat (CRISPR) Spacer Composition. Appl. Environ. Microbiol. 2013, 79, 5710-5720. [CrossRef] 
24. Toro, M.; Cao, G.; Ju, W.; Allard, M.; Barrangou, R.; Zhao, S.; Brown, E.; Meng, J. Association of Clustered Regularly Interspaced Short Palindromic Repeat (CRISPR) Elements with Specific Serotypes and Virulence Potential of Shiga Toxin-Producing Escherichia coli. Appl. Environ. Microbiol. 2014, 80, 1411-1420. [CrossRef] [PubMed]

25. Cady, K.C.; White, A.S.; Hammond, J.H.; Abendroth, M.D.; Karthikeyan, R.S.G.; Lalitha, P.; Zegans, M.E.; O’Toole, G.A. Prevalence, Conservation and Functional Analysis of Yersinia and Escherichia CRISPR Regions in Clinical Pseudomonas aeruginosa Isolates. Microbiology 2011, 157, 430-437. [CrossRef] [PubMed]

26. Ministry of Food and Drug Safety (MFDS). Processing Standards and Ingredient Specifications for Livestock Products; MFDS: Chongju, Korea, 2018.

27. Candrian, U.; Furrer, B.; Höfelein, C.; Meyer, R.; Jermini, M.; Lüthy, J. Detection of Escherichia coli and Identification of Enterotoxigenic Strains by Primer-Directed Enzymatic Amplification of Specific DNA Sequences. Int. J. Food Microbiol. 1991, 12, 339-351. [CrossRef]

28. Chapman, T.A.; Wu, X.-Y.; Barchia, I.; Bettelheim, K.A.; Driesen, S.; Trott, D.; Wilson, M.; Chin, J.J.-C. Comparison of Virulence Gene Profiles of Escherichia coli Strains Isolated from Healthy and Diarrheic Swine. Appl. Environ. Microbiol. 2006, 72, $4782-4795$. [CrossRef]

29. Grissa, I.; Vergnaud, G.; Pourcel, C. The CRISPRdb Database and Tools to Display CRISPRs and to Generate Dictionaries of Spacers and Repeats. BMC Bioinform. 2007, 8, 172. [CrossRef]

30. Biswas, A.; Gagnon, J.N.; Brouns, S.J.J.; Fineran, P.C.; Brown, C.M. CRISPRTarget. RNA Biol. 2013, 10, 817-827. [CrossRef]

31. Kaipainen, T.; Pohjanvirta, T.; Shpigel, N.Y.; Shwimmer, A.; Pyörälä, S.; Pelkonen, S. Virulence Factors of Escherichia coli Isolated from Bovine Clinical Mastitis. Vet. Microbiol. 2002, 85, 37-46. [CrossRef]

32. Guerra, S.T.; Orsi, H.; Joaquim, S.F.; Guimarães, F.F.; Lopes, B.C.; Dalanezi, F.M.; Leite, D.S.; Langoni, H.; Pantoja, J.C.F.; Rall, V.L.M.; et al. Short Communication: Investigation of Extra-Intestinal Pathogenic Escherichia coli Virulence Genes, Bacterial Motility, and Multidrug Resistance Pattern of Strains Isolated from Dairy Cows with Different Severity Scores of Clinical Mastitis. J. Dairy Sci. 2020, 103, 3606-3614. [CrossRef] [PubMed]

33. Zhang, D.; Zhang, Z.; Huang, C.; Gao, X.; Wang, Z.; Liu, Y.; Tian, C.; Hong, W.; Niu, S.; Liu, M. The Phylogenetic Group, Antimicrobial Susceptibility, and Virulence Genes of Escherichia coli from Clinical Bovine Mastitis. J. Dairy Sci. 2018, 101, 572-580. [CrossRef] [PubMed]

34. Connell, I.; Agace, W.; Klemm, P.; Schembri, M.; Marild, S.; Svanborg, C. Type 1 Fimbrial Expression Enhances Escherichia coli Virulence for the Urinary Tract. Proc. Natl. Acad. Sci. USA 1996, 93, 9827-9832. [CrossRef]

35. Langermann, S.; Palaszynski, S.; Barnhart, M.; Auguste, G.; Pinkner, J.S.; Burlein, J.; Barren, P.; Koenig, S.; Leath, S.; Jones, C.H.; et al. Prevention of Mucosal Escherichia coli Infection by FimH-Adhesin-Based Systemic Vaccination. Science 1997, 276, 607-611. [CrossRef] [PubMed]

36. Lehtolainen, T.; Pohjanvirta, T.; Pyörälä, S.; Pelkonen, S. Association between Virulence Factors and Clinical Course of Escherichia coli Mastitis. Acta Vet. Scand. 2003, 44, 203-205. [CrossRef]

37. Wenz, J.R.; Barrington, G.M.; Garry, F.B.; Ellis, R.P.; Magnuson, R.J. Escherichia coli Isolates' Serotypes, Genotypes, and Virulence Genes and Clinical Coliform Mastitis Severity. J. Dairy Sci. 2006, 89, 3408-3412. [CrossRef]

38. Nemeth, J.; Muckle, C.A.; Lo, R.Y. Serum Resistance and the TraT Gene in Bovine Mastitis-Causing Escherichia coli. Vet. Microbiol. 1991, 28, 343-351. [CrossRef]

39. Blum, S.E.; Leitner, G. Genotyping and Virulence Factors Assessment of Bovine Mastitis Escherichia coli. Vet. Microbiol. 2013, 163, 305-312. [CrossRef]

40. Croxen, M.A.; Finlay, B.B. Molecular Mechanisms of Escherichia coli Pathogenicity. Nat. Reviews. Microbiol. 2010, 8, 26-38. [CrossRef]

41. Croxen, M.A.; Law, R.J.; Scholz, R.; Keeney, K.M.; Wlodarska, M.; Finlay, B.B. Recent Advances in Understanding Enteric Pathogenic Escherichia coli. Clin. Microbiol. Rev. 2013, 26, 822-880. [CrossRef]

42. Liu, Y.; Liu, G.; Liu, W.; Liu, Y.; Ali, T.; Chen, W.; Yin, J.; Han, B. Phylogenetic Group, Virulence Factors and Antimicrobial Resistance of Escherichia coli Associated with Bovine Mastitis. Res. Microbiol. 2014, 165, 273-277. [CrossRef] [PubMed]

43. Müştak, H.K.; Günaydin, E.; Kaya, İ.B.; Salar, M.Ö.; Babacan, O.; Önat, K.; Ata, Z.; Diker, K.S. Phylo-Typing of Clinical Escherichia coli Isolates originating from Bovine Mastitis and Caninepyometra and Urinary Tract Infection by Means Ofquadruplex PCR. Vet. Q. 2015, 35, 194-199. [CrossRef] [PubMed]

44. Ombarak, R.A.; Hinenoya, A.; Awasthi, S.P.; Iguchi, A.; Shima, A.; Elbagory, A.-R.M.; Yamasaki, S. Prevalence and Pathogenic Potential of Escherichia coli Isolates from Raw Milk and Raw Milk Cheese in Egypt. Int. J. Food Microbiol. 2016, $221,69-76$. [CrossRef] [PubMed]

45. Xue, C.; Sashital, D.G. Mechanisms of Type I-E and I-F CRISPR-Cas Systems in Enterobacteriaceae. EcoSal Plus 2019, 8. [CrossRef] [PubMed]

46. Savitskaya, E.; Lopatina, A.; Medvedeva, S.; Kapustin, M.; Shmakov, S.; Tikhonov, A.; Artamonova, I.I.; Logacheva, M.; Severinov, K. Dynamics of Escherichia coli Type I-E CRISPR Spacers over 42,000 Years. Mol. Ecol. 2017, 26, 2019-2026. [CrossRef]

47. Delannoy, S.; Beutin, L.; Fach, P. Use of Clustered Regularly Interspaced Short Palindromic Repeat Sequence Polymorphisms for Specific Detection of Enterohemorrhagic Escherichia coli Strains of Serotypes O26:H11, O45:H2, O103:H2, O111:H8, O121:H19, O145:H28, and O157:H7 by Real-Time PCR. J. Clin. Microbiol. 2012, 50, 4035-4040. [CrossRef] 
48. Johnson, T.J.; Nolan, L.K. Pathogenomics of the Virulence Plasmids of Escherichia coli. Microbiol. Mol. Biol. Rev. MMBR 2009, 73, 750-774. [CrossRef]

49. Gyles, C.; Boerlin, P. Horizontally Transferred Genetic Elements and Their Role in Pathogenesis of Bacterial Disease. Vet. Pathol. 2014, 51, 328-340. [CrossRef]

50. García-Gutiérrez, E.; Almendros, C.; Mojica, F.J.M.; Guzmán, N.M.; García-Martínez, J. CRISPR Content Correlates with the Pathogenic Potential of Escherichia coli. PLoS ONE 2015, 10, e0131935. [CrossRef]

51. Stern, A.; Keren, L.; Wurtzel, O.; Amitai, G.; Sorek, R. Self-Targeting by CRISPR: Gene Regulation or Autoimmunity? Trends Genet. 2010, 26, 335-340. [CrossRef]

52. Babu, M.; Beloglazova, N.; Flick, R.; Graham, C.; Skarina, T.; Nocek, B.; Gagarinova, A.; Pogoutse, O.; Brown, G.; Binkowski, A.; et al. A Dual Function of the CRISPR-Cas System in Bacterial Antivirus Immunity and DNA Repair. Mol. Microbiol. 2011, 79, 484-502. [CrossRef] [PubMed]

53. Louwen, R.; Staals, R.H.J.; Endtz, H.P.; van Baarlen, P.; van der Oost, J. The Role of CRISPR-Cas Systems in Virulence of Pathogenic Bacteria. Microbiol. Mol. Biol. Rev. MMBR 2014, 78, 74-88. [CrossRef] [PubMed]

54. Aydin, S.; Personne, Y.; Newire, E.; Laverick, R.; Russell, O.; Roberts, A.P.; Enne, V.I. Presence of Type I-F CRISPR/Cas Systems Is Associated with Antimicrobial Susceptibility in Escherichia coli. J. Antimicrob. Chemother. 2017, 72, 2213-2218. [CrossRef] [PubMed]

55. Bozic, B.; Repac, J.; Djordjevic, M. Endogenous Gene Regulation as a Predicted Main Function of Type I-E CRISPR/Cas System in E. coli. Molecules 2019, 24, 784. [CrossRef]

56. Leiman, P.G.; Basler, M.; Ramagopal, U.A.; Bonanno, J.B.; Sauder, J.M.; Pukatzki, S.; Burley, S.K.; Almo, S.C.; Mekalanos, J.J. Type VI Secretion Apparatus and Phage Tail-Associated Protein Complexes Share a Common Evolutionary Origin. Proc. Natl. Acad. Sci. USA 2009, 106, 4154-4159. [CrossRef]

57. Bingle, L.E.; Bailey, C.M.; Pallen, M.J. Type VI Secretion: A Beginner's Guide. Curr. Opin. Microbiol. 2008, 11, 3-8. [CrossRef] 